\title{
SUNFLOWER COMPETITION IN WHEAT
}

\author{
G. R. Gillespie and S. D. Miller
}

\section{INTRODUCTION}

Sunflower-wheat rotations are common in many areas of North Dakota. With this rotation, volunteer sunflower is often a problem in wheat planted the following year. Yield losses from volunteer sunflower competition in corn and soybean are substantial and vary with the density and length of competition. Sunflower's extensive taproot system enables it to compete successfully with crops for limited moisture and nutrients. In addition, sunflower's large leaves restrict the photosynthetic ability of shorter plants through shading.

Wheat yield losses from various sunflower densities and durations of competition have not been determined previously. The objectives of this research were to determine the influence of sunflower density, duration of competition and rate of control on wheat yield.

\section{MATERIALS AND METHODS}

Field experiments were conducted in 1981 at Fargo, Casselton and Absaraka, North Dakota on areas where sunflower had been grown the previous season. Wheat plantings on May 1 at Fargo and May 5 at Casselton represented normal seeding dates. Late-seeded wheat was planted on May 20, 22 and 29 at Fargo, Absaraka and Casselton, respectively. Plants were maintained free of weeds other than sunflower during the growing season with herbicides and hand weeding. Each experiment was a randomized complete block with four replications. Experimental units were 6 by $12 \mathrm{ft}$. Data collected included wheat height, tillers/plant, kernels/spike, weight of 200 kernels, and yield. Sunflower visual control ratings were taken 1,5 and 18 days after herbicide treatment in the sunflower competition following herbicide application experiment.

Sunflower densities. Sunflower densities of $0,0.5,1$, 3,9 , and 23 plants per 1.2 square yards were established

Gillespie is former graduate research assistant and Miller is associate professor, Department of Agronomy. in wheat by hand thinning as soon after emergence as possible. The sunflower were left to compete with the wheat until harvest.

Duration of sunflower competition. Sunflower at natural densities (averaged 24 plants per 1.2 square yards) were removed by hand at the three-, five- and flag-leaf stages of wheat to determine the influence of duration of sunflower competition on wheat yield. In addition, there was a no-removal treatment which had season-long sunflower competition and a weed-free treatment in which the sunflowers were removed immediately after emergence.

Sunflower competition following herbicide application. Greenhouse experiment. Sunflower seeds were placed 2 inches deep in greenhouse potting soil contained in 1 qt pots and thined after emergence to 1 plant per pot. A 0.25-inch layer of vermiculite was placed on the soil surface to minimize water evaporation from the soil. Postemergence applications of bromoxynil, MCPA butoxyethanol ester, and bromoxynil plus MCPA all at 6 ounces per acre were applied to sunflower in the fourleaf stage with a moving nozzle sprayer that delivered 17 gallons per acre at 40 psi. Sunflower daily water use was determined by measuring the amount of water required to bring the soil to field capacity on a weight basis. Water use measurements were taken every 24 hours for eight days after herbicide treatment and data expressed as percent of a control which received no herbicide application. The experiment was completely random with four repetitions.

Field experiments. Natural sunflower densities (averaged 53 plants per 1.2 square yards) were sprayed with either bromoxynil at 4 ounces per acre, MCPA butoxyethanol ester at 8 ounces per acre, or bromoxynil plus MCPA each at 4 ounces per acre at the four- to five-leaf stage of wheat. Herbicide treatments were applied with a bicycle wheel plot sprayer that delivered 8.5 gallons per acre at $40 \mathrm{psi}$. In addition, the experiment included a treatment where sunflower were cut off at the soil surface at the time of herbicide application.

\section{RESULTS AND DISCUSSION}

Sunflower densities. Wheat yield decreased as the sunflower density increased from 0 to 23 plants per 1.2 
square yard (Table 1). Wheat yields were decreased 5, 7, 11,19 , and 33 percent compared to weed free plots with season long competition of sunflower at $0.5,1,3,9$, and 23 plants per 1.2 square yards, respectively, averaged over locations and seeding dates. Sunflower was more competitive in wheat seeded in late May than early May, particularly at the lower sunflower densities. Yields of wheat seeded in early May were reduced 16 percent compared to weed free plots by season long competition of nine sunflower plants per 1.2 square yards; however, only three sunflower plants per 1.2 square yards were required to reduce yield of wheat seeded in late May by a similar amount. In addition, yield of wheat seeded in early May was greater than yield of wheat seeded in late May at all sunflower densities. Wheat yields averaged 42 percent more when wheat was seeded in early than late May, averaged over locations.

Table 1. Wheat yield, height, tillers/plant, kernels/spike, and 200 kernel weight as influenced by season long competition of sunflower at varying densities.

\begin{tabular}{|c|c|c|c|c|c|c|c|}
\hline $\begin{array}{l}\text { Sunflower } \\
\text { density }\end{array}$ & Normal' & $\begin{array}{l}\text { Wheat yield } \\
\text { Late }^{2}\end{array}$ & Mean & $\begin{array}{l}\text { Wheat } \\
\text { height }\end{array}$ & $\begin{array}{l}\text { Tillersl } \\
\text { plant }\end{array}$ & $\begin{array}{c}\text { Kernels/ } \\
\text { spike }\end{array}$ & $\begin{array}{l}\text { Kernel } \\
\text { welght }\end{array}$ \\
\hline \multicolumn{8}{|c|}{$\left(\right.$ No./1.2 $\left.\mathrm{yd}^{2}\right)-(\mathrm{bu} / \mathrm{A})-(\mathrm{inch})$} \\
\hline 0 & 34.1 & 21.0 & 27.5 & 25 & 2.7 & 33 & 4.94 \\
\hline 0.5 & 32.9 & 19.4 & 26.1 & 24 & 2.6 & 31 & 4.93 \\
\hline 1 & 32.0 & 19.3 & 25.6 & 24 & 2.4 & 32 & 4.96 \\
\hline 3 & 31.7 & 17.3 & 24.5 & 25 & 2.6 & 32 & 4.97 \\
\hline 9 & 28.5 & 16.0 & 22.2 & 25 & 2.4 & 31 & 4.91 \\
\hline 23 & 23.7 & 13.0 & 18.3 & 24 & 2.1 & 29 & 4.91 \\
\hline LSD 0.05 & 4.4 & 2.7 & 2.6 & NS & 0.3 & 3 & NS \\
\hline
\end{tabular}

'Averaged over Fargo and Casselton wheat seeded in early May.

${ }^{2}$ Averaged over Cassselton and Absaraka wheat seeded in late May.

Wheat height and 200 kernel weight were not affected by season long competition at any sunflower density (Table 1). However,tillers per wheat plant and kernels per spike decreased as sunflower density increased from 0 to 23 plants per square yard. The number of tillers per plant decreased from 2.7 to 2.1 and the number of kernels per spike decreased from 33 to 29 as the sunflower density increased from 0 to 23 plants per square yard. These data indicate that wheat yield reductions caused by season long competition of sunflower at several densities was due to fewer tillers per plant and kernels per spike rather than a decrease in 200 kernel weight.

Duration of sunflower competition. Wheat yields were not reduced until sunflower removals were delayed until the wheat flag-leaf stage (Table 2). Further, sunflower was more competitive with wheat seeded in late than early May. Yield of wheat seeded in early and late May was reduced 14 and 31 percent, respectively, compared to weed-free plots if sunflower at an average density of 24 plants per 1.2 square yard were allowed to compete until the flag-leaf stage. Yields were greater for wheat seeded in early than late May at all durations of sunflower competition.

Wheat height and the number of tillers/plant were reduced if sunflower at 24 plants per 1.2 square yards were allowed to compete until the flag-leaf stage of
Table 2. Wheat yield, height, tillers/plant, kernels/spike and 200 kernel weight as influenced by duration of sunflower competition.

\begin{tabular}{|c|c|c|c|c|c|c|c|}
\hline $\begin{array}{l}\text { Time of } \\
\text { removal' }\end{array}$ & Normal $^{2}$ & $\begin{array}{l}\text { Wheat yield } \\
\text { Late }^{3}\end{array}$ & Mean & $\begin{array}{l}\text { Wheat } \\
\text { height }\end{array}$ & $\begin{array}{l}\text { Tillersl } \\
\text { plant }\end{array}$ & $\begin{array}{l}\text { Kernels/ } \\
\text { spike }\end{array}$ & $\begin{array}{l}\text { Kernel } \\
\text { weight }\end{array}$ \\
\hline \multicolumn{8}{|c|}{ (Wheat stage) } \\
\hline Weed free & 37.2 & 23.4 & 29.6 & 26 & 3.0 & 32 & 4.92 \\
\hline 3-leaf & 35.9 & 21.9 & 28.1 & 26 & 3.0 & 33 & 4.86 \\
\hline 5-leaf & 35.3 & 21.3 & 27.5 & 26 & 2.9 & 32 & 4.82 \\
\hline Flag-leaf & 32.0 & 16.1 & 23.1 & 24 & 2.4 & 31 & 5.06 \\
\hline \multicolumn{8}{|l|}{ No } \\
\hline removal & 26.7 & 15.5 & 20.5 & 25 & 2.1 & 29 & 5.10 \\
\hline LSD 0.05 & 2.8 & 2.8 & 2.1 & 1 & 0.3 & 3 & 0.15 \\
\hline
\end{tabular}

'Sunflower density averaged 24 plants $/ 1.2 \mathrm{yd}^{2}$.

Averaged over Fargo and Casselton wheat seeded in early May.

'Averaged over Fargo, Casselton, and Absaraka wheat seeded in late May

wheat (Table 2). Sunflower competition until the flagleaf stage of wheat reduced wheat height 2 inches, and reduced the number of tillers per plant by 0.6 compared to weed free plots. The number of wheat kernels per spike was not reduced until sunflower were allowed to compete season long. Season long competition of sunflower increased wheat 200 kernel weight compared to weed free plots. The increase in 200 kernel weight may be due to the presence of fewer kernels per unit area; the kernels that were present were larger. These data indicate that wheat yield losses caused by increased duration of sunflower comptition are due to a decreased number of tillers per plant and kernels per spike,

Sunflower competition following herbicide application. Greenhosue experiment. Sunflower died more rapidly and used less water after being sprayed with bromoxynil plus MCPA or bromoxynil compared to MCPA (Figure 1). Sunflower water use after bromoxynil plus MCPA or bromoxynil application dropped to approximately 20 percent of the untreated control within 24 hours, to approximately 2 percent of the untreated control at three days, and the plants were controlled by day five. Sunflower water use remained near 40 percent of the untreated control for three days following MCPA application; however, sunflower water use dropped linearly form 40 to 5 percent of the untreated control from three to eight days after MCPA application.

cont. on page 25

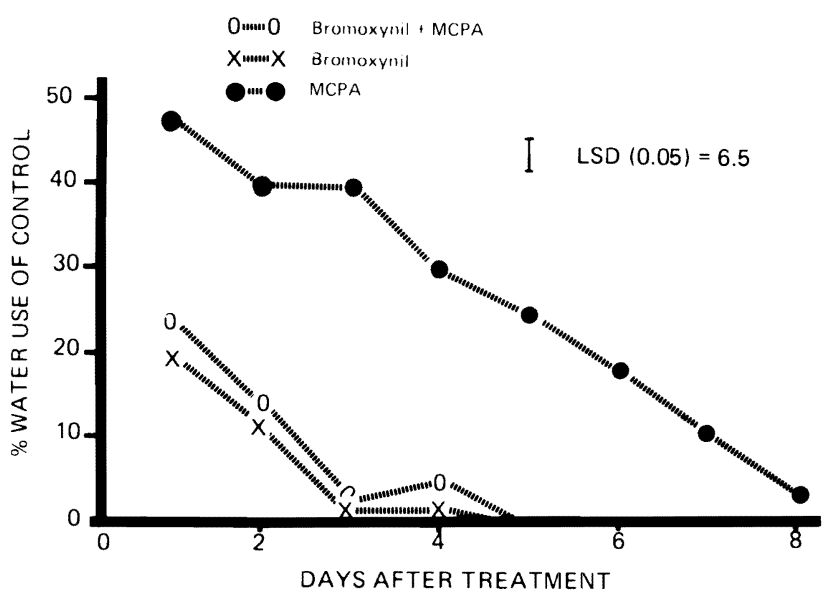

Figure 1. Sunflower water use after herbicide treat. ment in the greenhouse expressed as percent of the un. treated control. 
realized, or will be in the next few years. The water issues are:

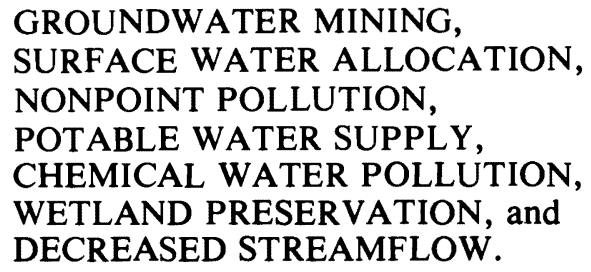

Many of these issues involve problems among political jurisdictions. For example, "surface water allocation" and "decreased streamflow" are both issues among Missouri River Basin states. Wetlands preservation, on the other hand, is primarily an issue of national versus local values, i.e., wetlands have values to society in their natural state, yet may be more valuable to local areas if converted to alternative uses.

The final category of issues, public policy issues, is what all issues eventually become if not resolved. Those that were pointedly policy issues among the top- 20 were:

\author{
PUBLIC DECISION PROCESSES IN NATURAL \\ RESOURCES, \\ NATIONAL ECONOMY, \\ PUBLIC LAND DEVELOPMENT, and \\ ECONOMICS OF ENVIRONMENTAL \\ REGULATION.
}

While there is little that can be done about the "national economy" from here in North Dakota, we are concerned about "public decision processes" and the costs and benefits of "environmental regulation."

\section{CONCLUSION}

Many of the issues tagged as emerging in this study may be more aptly described as persisting, yet they may emerge in different geographic areas or contexts. The identification of natural resource issues significant to North Dakota's future will assist federal agencies, especially the U.S. Geological Survey, with setting their long range plans and goals, and should ultimately lead to amelioration of the issues.

Perhaps the most significant outcome of the study was not identification of important issues per se, but rather that a consensus was reached among scores of experts on what is and what will be important in the near future.

\section{LITERATURE CITED}

1. Brown, Bernice. DELPHI PROCESS: A Methodology Used for the Elicitation of Opinions of Experts, The RAND Corporation, Santa Monica, California, 1968.

2. Leitch, Jay A., F. Larry Leistritz, A. Clyde Vollmers, and Rodney K. Stroh. Natural Resource Issue Identification, Department of Agricultural Economics, Agricultural Experiment Station, North Dakota State University, Fargo, June 1983.

\section{cont. from page 4}

Field experiment. Volunteer sunflower control was more rapid in wheat sprayed postemergence with bromoxynil plus MCPA or bromoxynil alone compared to MCPA alone (Table 3). Sunflower visual control ratings were 99,96 , and 44 percent five days after bromoxynil plus MCPA, bromoxynil, and MCPA application, respectively. Sunflower control had increased to 89 percent by 18 days after MCPA application. Despite the slower rate of control and increased water use of sunflower treated with MCPA compared to bromoxynil or bromoxynil plus MCPA, wheat yields were similar.

Table 3. The influence of herbicide treatment on rate of sunflower control and wheat yield.

\begin{tabular}{|c|c|c|c|c|c|}
\hline Treatment' & \multicolumn{3}{|c|}{ Sunflower visual control ${ }^{2}$} & Day 18 & $\begin{array}{l}\text { Wheat }{ }^{2} \\
\text { yield }\end{array}$ \\
\hline & (OZ/A) & 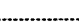 & \%) & 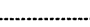 & (bu/A) \\
\hline $\begin{array}{l}\text { Bromoxynil + MCPA } \\
\text { Bromoxynil } \\
\text { MCPA } \\
\text { Cut Control } \\
\text { LSD (0.5) }\end{array}$ & $\begin{array}{c}4+4 \\
4 \\
8\end{array}$ & $\begin{array}{l}28 \\
16 \\
33\end{array}$ & $\begin{array}{r}99 \\
96 \\
44 \\
5\end{array}$ & $\begin{array}{r}99 \\
100 \\
89\end{array}$ & $\begin{array}{l}27.8 \\
25.6 \\
25.6 \\
27.5 \\
\text { NS }\end{array}$ \\
\hline
\end{tabular}

Sunflower density at treatment averaged 53 plants $/ 1.2 \mathrm{yd}^{2}$. May.

\section{CONCLUSIONS}

Wheat following sunflower should be seeded early since late seeding reduced wheat yield. Sunflower densities of 9 plants per 1.2 square yards should be removed before the wheat flag-leaf stage to prevent yield reductions. Equivalent wheat yields would be obtained if volunteer sunflower are sprayed postemergence with MCPA, bromoxynil or bromoxynil plus MCPA by the 5-leaf stage of wheat.

\section{LITERATURE CITED}

1. Abernathy, J.R., J. V. Schrib, K. O. Adkins, and J. R. Supak. 1976. Response of volunteer sunflower to herbicidal control. Proc. South Weed Sci. Soc. 29:81.

2. Auwater, G.E., and J. D. Nalewaja. 1976. Volunteer sunflower competition in soybeans. Proc. North Cent. Weed Contr. Conf. 31:34.

3. Robbins, W. W., A. S. Crafts, and R. N. Raynor. 1952. Weed control. McGraw-Hill Book Co., Inc., New York. pages 85-116.

4. Robinson, R. G. 1978. Production and culture, pages 89-135. In J. F. Carter (ed.). Sunflower Science and Technology. Am. Soc. Agron., Madison, Wisconsin. 